\title{
Thickness of marine Holocene sediment in the Gulf of Trieste (northern Adriatic Sea)
}

\author{
Ana Trobec ${ }^{1}$, Martina Busetti ${ }^{2}$, Fabrizio Zgur ${ }^{2}$, Luca Baradello ${ }^{2}$, Alberto Babich ${ }^{2,3}$, Andrea Cova ${ }^{2}$, \\ Emiliano Gordini ${ }^{2}$, Roberto Romeo ${ }^{2}$, Isabella Tomini ${ }^{2}$, Sašo Poglajen ${ }^{4}$, Paolo Diviacco ${ }^{2}$, and \\ Marko Vrabec ${ }^{1}$ \\ ${ }^{1}$ University of Ljubljana, Faculty of Natural Sciences and Engineering, Department of Geology, \\ Aškerčeva cesta 12, 1000 Ljubljana, Slovenia \\ ${ }^{2}$ OGS - Istituto Nazionale di Oceanografia e di Geofisica Sperimentale, Borgo Grotta Gigante 42/c, \\ 34010 Sgonico, Trieste, Italy \\ ${ }^{3}$ Università di Trieste, Dipartimento di Matematica e Geoscienze, Via Weiss 2, 34127 Trieste, Italy \\ ${ }^{4}$ Harpha Sea d.o.o., Čevljarska ulica 8, 6000 Koper, Slovenia \\ Correspondence: Ana Trobec (ana.trobec@geo.ntf.uni-lj.si)
}

Received: 7 December 2017 - Discussion started: 18 December 2017

Revised: 23 May 2018 - Accepted: 31 May 2018 - Published: 14 June 2018

\begin{abstract}
We use various geophysical datasets (multibeam and singlebeam echosounder data, sub-bottom profiling Chirp and sonar data and very high-resolution boomer seismic data) along with published sedimentological data and depth data from nautical charts in order to create models of the depth of the seafloor and the base of Holocene marine sediment in the Gulf of Trieste. The two models are later used in order to calculate the thickness of marine Holocene sediment which has been depositing on the Late Pleistocene alluvial plain since the Holocene transgression in the Italian and Slovenian parts of the gulf. Thicker Holocene marine sedimentary sequences averaging at around $5 \mathrm{~m}$ are characteristic for the southeastern part of the gulf. In other parts of the gulf the Holocene marine sedimentary cover is very thin or even absent, except in close proximity to the shoreline and fluvial sediment sources, in the area of the Trezza Grande paleodelta and above topographic depressions of the Late Pleistocene base. The presented datasets available from the OGS SNAP data repository (http://doi.org/cpz2) represent a valuable reference for a wide variety of research disciplines dealing with the dynamic Earth system in the Gulf of Trieste and could be used as a valuable tool for designing sampling and geophysical campaigns in the studied area.
\end{abstract}

1

The Gulf of Trieste is a shallow gulf with an average depth at around $20 \mathrm{~m}$ located in the northernmost part of the Adriatic Sea where it is surrounded by Italian, Slovenian and Croatian coasts (Fig. 1). After the Last Glacial Maximum with the onset of the Holocene transgression, marine sediment started depositing approximately 10000 years ago in this area (Marocco, 1991; Ogorelec et al., 1991, 1997; Lambeck et al., 2004; Covelli et al., 2006; Ogrinc et al., 2007; Trincardi et al., 2011b).

Early research of Holocene marine sediment in the Gulf of Trieste was mainly limited to sedimentological and geo- chemical investigations of data acquired with a relatively small number of cores and wells located onshore and offshore the gulf in the 80s and 90s (Ogorelec et al., 1981, 1991, 1997; Marocco et al., 1984; Marocco, 1989, 1991; Faganeli et al., 1991; Gordini et al., 2002; Covelli et al., 2006; Ogrinc et al., 2007) and investigations for the Italian Marine Geological Map 1:250000 of Venice (Trincardi et al., 2011a, b). The development of cost-effective geophysical methods in recent years resulted in a number of geophysical surveys undertaken in the last decade that were focused on high-resolution geophysical investigation of the seafloor and the sub-seafloor geological structure of the gulf (Gordini et al., 2003, 2004, 2006; Gordini, 2007, 2009; Romeo, 


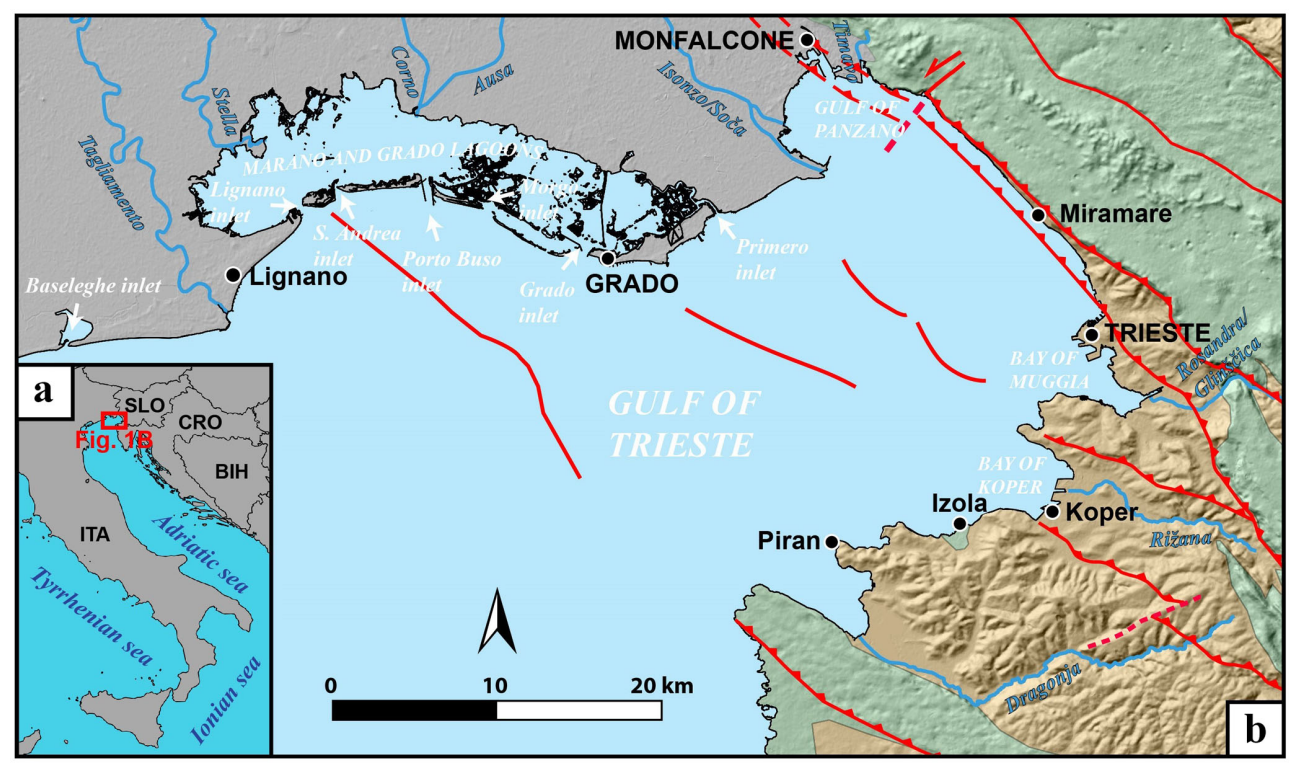

Figure 1. Location of the study area; (a) regional map; (b) a simplified geological map of the area (following Biolchi et al., 2016; Busetti et al., 2010a; Carulli et al., 2006; Carulli, 2011; EMODnet, 2018; Jurkovšek et al., 2016; Placer et al., 2010; Placer, 2015; Pleničar et al., 1969). Mesozoic carbonates are marked with green, Eocene flysch with orange and Quaternary sediment with grey.

2009; Trincardi et al., 2011a, b, 2014; Kolega and Poklar, 2012; Slavec, 2012; Zampa et al., 2015; Zecchin et al., 2015; Trobec, 2015; Trobec et al., 2016, 2017). Some of these extensive datasets along with additional unpublished data spanning over a major part of the gulf allowed us to assess the thickness of the Holocene marine sediment in the Gulf of Trieste.

This work aims to present the first comprehensive model of the distribution and thickness of Holocene marine sediment in the Slovenian and Italian parts of the Gulf of Trieste. The model is derived from geophysical, core/well, and nautical chart data and in parts is complemented by the published Holocene marine thicknesses from Trincardi et al. (2011b).

\section{Geological setting of the study area}

A simplified geological overview of the surroundings of the Gulf of Trieste is shown in Fig. 1b and consists of Quaternary alluvial sediment (grey) of the Friuli plain in the north, Cretaceous-Paleogene carbonates (green) of the Classical Karst in the northeast and Paleogene marls and sandstones of the flysch (orange) of the Istria peninsula and Trieste coastline in the southern and eastern parts of the gulf. A similar geological sequence can be observed in geophysical data offshore from the gulf area where the carbonate platform is followed by a flysch succession which is overlain by a few hundred metres of Quaternary sediment deposited during the transgressive-regressive cycles (Busetti et al., 2010a, b; Cimolino et al., 2010; Vrabec et al., 2014). The youngest sedimentary sequence in the Gulf of Trieste is represented by Holocene marine sediment which has been depositing for the last 10000 years since the onset of the Holocene transgression following the Younger Dryas (Ogorelec et al., 1981, 1997; Lambeck et al., 2004; Covelli et al., 2006; Trincardi et al., 2011b; Zecchin et al., 2015). Many authors suggest that the base on which marine sediment has been depositing represents relict continental-paralic sedimentary environments predating the Holocene sea transgression in the Gulf of Trieste (Ogorelec et al., 1981, 1991, 1997; Marocco, 1989; Lambeck et al., 2004; Covelli et al., 2006; Trincardi et al., 2011b; Slavec, 2012; Zecchin et al., 2015; Trobec, 2015; Trobec et al., 2017). The sediments of the Holocene marine transgression provided a thin and discontinuous deposit occurring on an erosive surface of the Late Pleistocene sediments due to subaerial exposure (Trincardi et al., 2011a).

\section{Data used and modelling of the different surfaces}

Numerous geophysical surveys were conducted between 2000 and 2015 in the Gulf of Trieste by the Istituto Nazionale di Oceanografia e di Geofisica Sperimentale (OGS) and by Harpha Sea d.o.o. in cooperation with the Department of Geology of the University of Ljubljana (Figs. 4 and 5, Tables 2 and 3). Most of the data and results from these surveys were so far published only in internal reports and/or theses and are here presented to a wider audience for the first time.

Geophysical data were correlated and calibrated with core/well data previously published in other scientific publications (Table 1 and Figs. 2 and 3; Ogorelec et al., 1981, 1991, 1997; Marocco et al., 1984; Marocco, 1989; Gordini et al., 2002; Covelli et al., 2006; Romeo, 2009; Trincardi et al., 2011b; Zecchin et al., 2015). The cores/wells usually doc- 
Table 1. Previously published wells and cores used in this study with reported ${ }^{14} \mathrm{C}$ ages. The $>$ symbol indicates that the core contains only Holocene marine sediment. The "/" symbol indicates that data were not reported or investigated in the original publication.

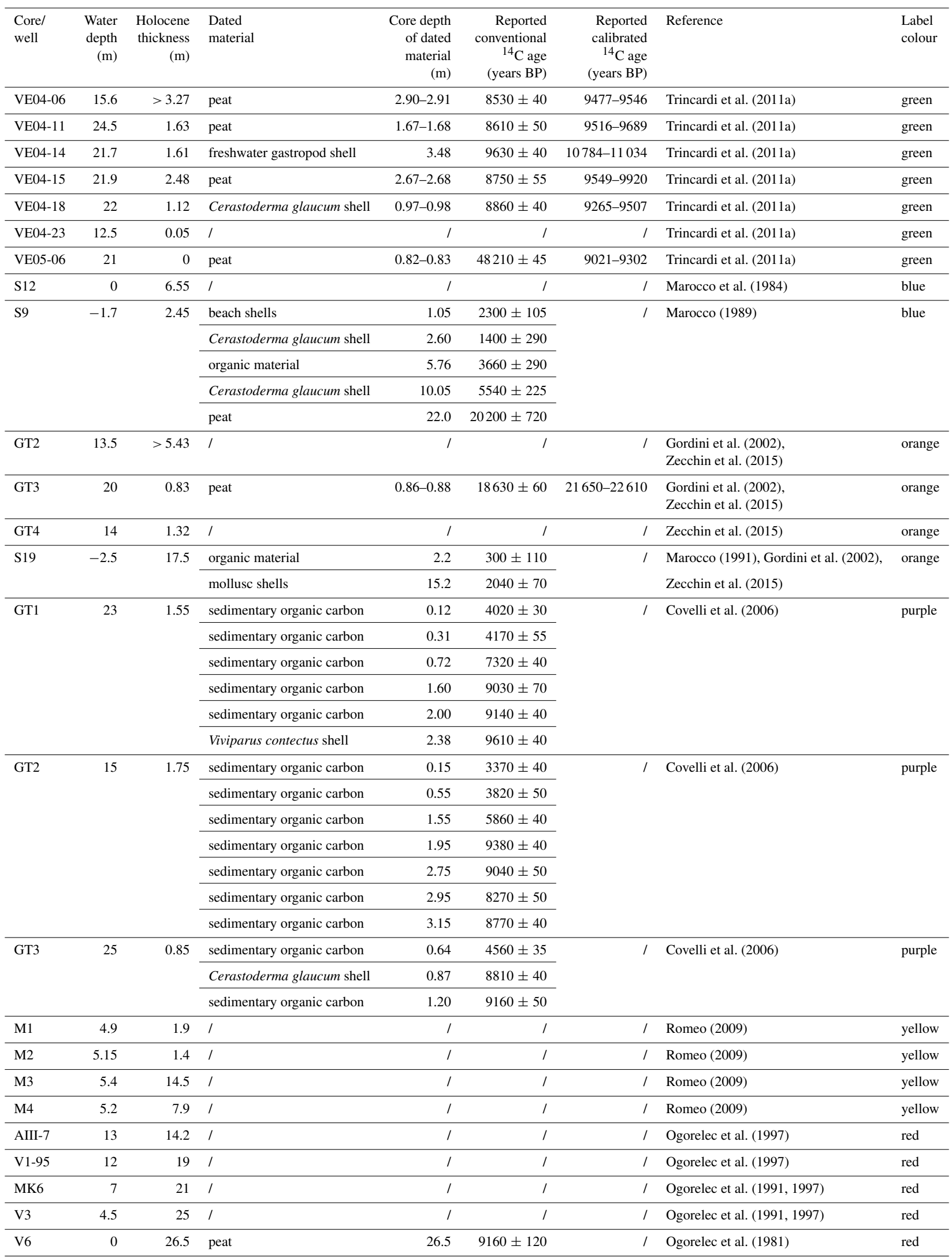



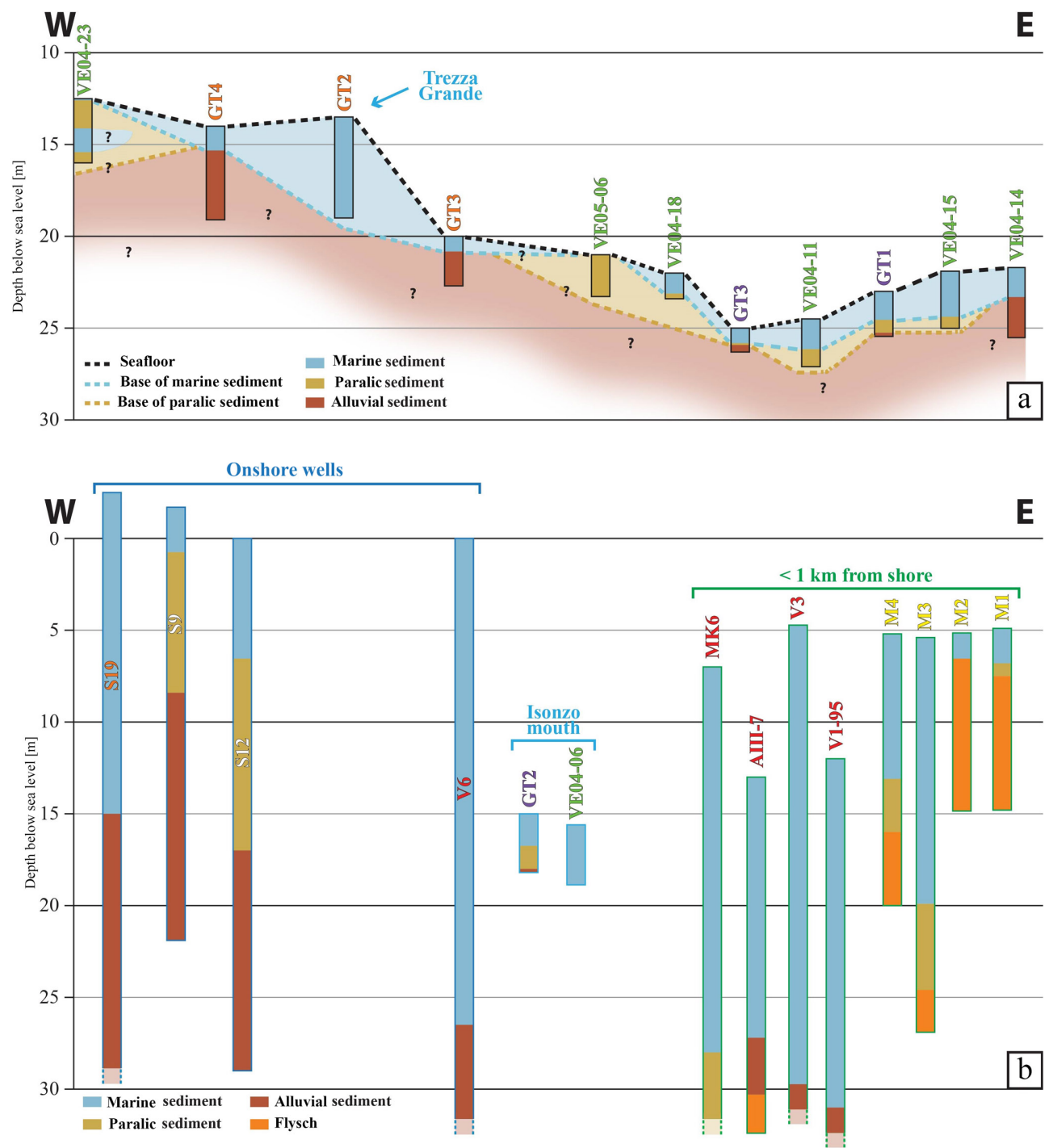

Figure 2. Simplified stratigraphy of all the cores and wells used in this study (Table 1; for details see Ogorelec et al., 1981, 1991, 1997; Marocco et al., 1984; Marocco, 1989; Gordini et al., 2002; Covelli et al., 2006; Romeo, 2009; Trincardi et al., 2011b; Zecchin et al., 2015). Note that the distance between the cores/wells is not in scale, (a) a simplified W-E stratigraphic profile of the cores located in the central part of the Gulf of Trieste; (b) wells and cores used in the study that were not suitable for the stratigraphic profile due to their location or proximity to the shore or fluvial sedimentary sources (see Figs. 4 and 5 for location). Wells outlined in dark blue are located onshore. Cores outlined in bright blue are located in close proximity of the present-day Isonzo river mouth. Cores outlined in green are located less than $1 \mathrm{~km}$ from the shoreline. Dashed bottoms of wells indicate that their whole stratigraphy is not illustrated in the figure and that the reader should refer to the original publications for further information.

ument a transition from an alluvial to paralic and later marine sedimentary environment. However, in some cores the marine or paralic sedimentary sequence is absent or the marine and paralic sediments are deposited directly on the bedrock (Figs. 2, 3 and 8d).

The calibration of the geophysical data with the stratigraphy of core/well data available for the Gulf of Trieste (Table 1) indicates that the Holocene marine sediment is represented on high-resolution acoustic sonar and seismic boomer profiles as a characteristic transparent acoustic/seismic facies which shows absent or very faint low-amplitude internal reflections (e.g. Fig. 3). On geophysical profiles Holocene paralic and/or Late Pleistocene continental sedimentary units are separated from the Holocene marine sediment by a prominent middle- to high-amplitude reflection and furthermore demonstrate significantly dissimilar acoustic facies containing several reflections of varying reflection geometries, amplitudes and continuity (Romeo, 2009; Slavec, 2011, 2012; Trobec, 2015; Trobec et al., 2017). 


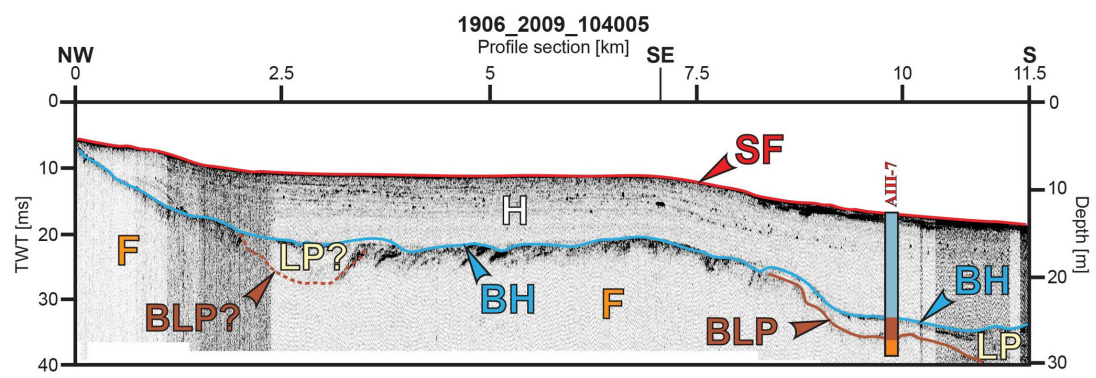

Figure 3. An example of an acoustic profile, acquired along the northern coast of the Istria Peninsula, which is correlated with the core AIII-7 from Ogorelec et al. (1997) (SF: seafloor, H: Holocene marine sediment, BH: reflector that marks the base of the Holocene sediment, LP: Late Pleistocene sediment, BLP: base of the Late Pleistocene sediment, F: flysch, TWT: two-way travel time). For the location of the profile, see Fig. 5.

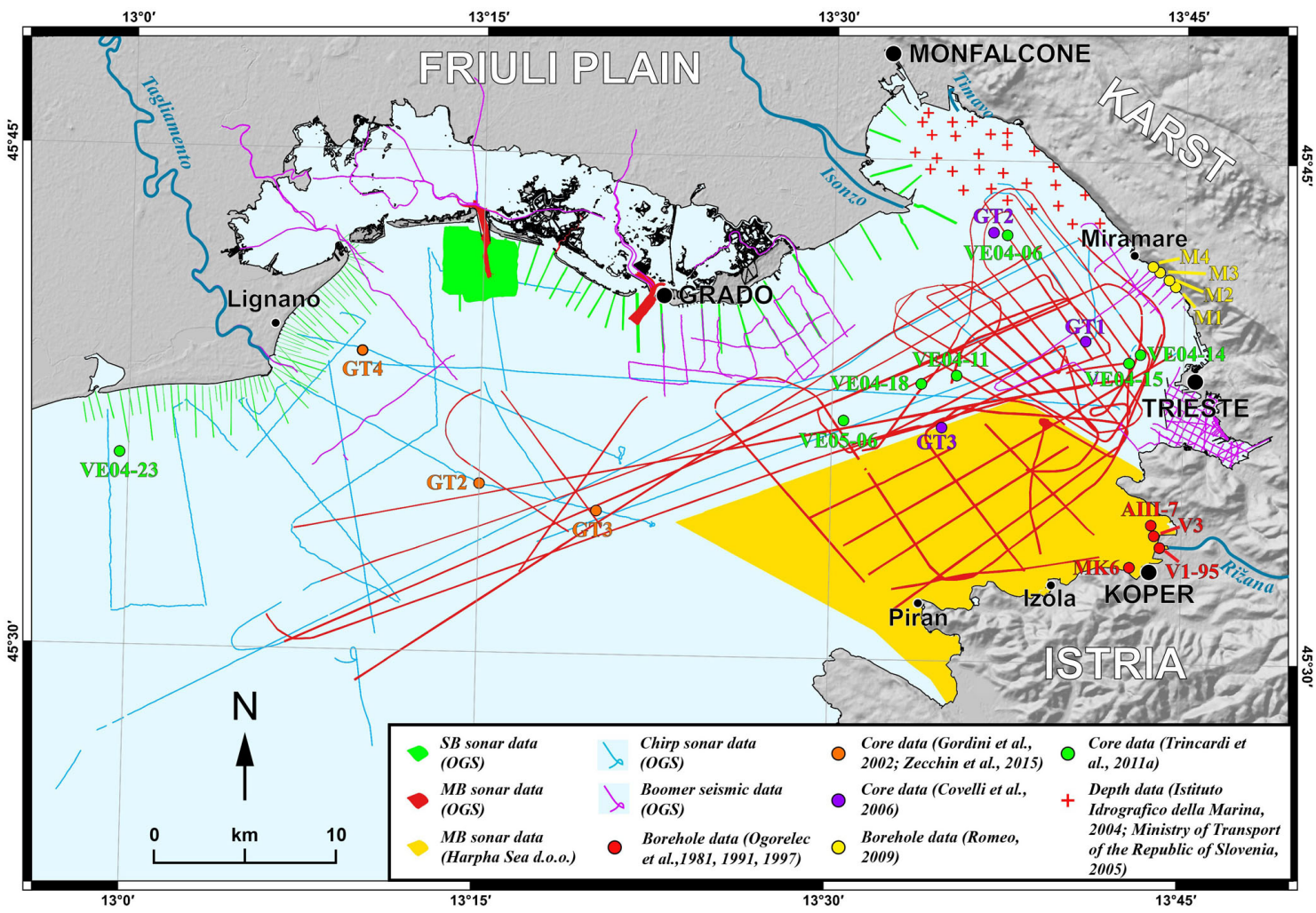

Figure 4. Locations of the datasets used for the bathymetric model of the Gulf of Trieste.

Reported conventional radiocarbon ages from published core/well data (Table 1) show that Holocene marine sediment started depositing on the alluvial sedimentary sequence approximately 9150 years BP in the Gulf of Trieste. The Holocene marine sequence started depositing later where it overlies paralic sequences for which conventional radiocarbon ages younger than approximately 8800 years BP are reported (Table 1). The reported radiocarbon ages in Table 1 clearly show that the alluvial- or paralic-Holocene marine boundary in the Gulf of Trieste is diachronous.

Geophysical datasets along with previously published core/well data allowed us to create a model of the distribution and thickness of Holocene marine sediment in the Italian and Slovenian parts of the gulf. The different datasets and methods used to create each model are described in detail in the subsequent subsections.

\subsection{The bathymetric model}

In order to create the bathymetric model of the Gulf of Trieste we used multibeam and singlebeam sonar data complemented with high-resolution single-channel seismic data (boomer and Chirp profiles) (Fig. 4, Tables 2 and 3). In addition, water depths of 28 points in the Gulf of Panzano were 
determined from the Slovenian nautical chart of the Gulf of Trieste (Ministry of Transport of the Republic of Slovenia, 2005) and the Da Punta Tagliamento a Pula nautical chart (Istituto Idrografico della Marina, 2004). We also used depths of published cores/wells in the gulf (Table 1, Fig. 2). The used datasets are depicted in Fig. 4. In order to constrain the model, we used the coastline contour for which we assumed a seafloor depth value equal to $0 \mathrm{~m}$ above sea level.

Multibeam sonar data included data acquired during the reflection seismic surveys in the central and Slovenian parts of the gulf in the years 2009 and 2013 (Table 2). In addition, a multibeam-based bathymetric model of Slovenian territorial waters (Slavec, 2012) acquired by Harpha Sea d.o.o. was also used. Smaller areas surveyed by OGS by multibeam sonar also include three areas in front of the GradoMarano lagoon: the Porto Buso inlet, Morgo inlet and Grado inlet (Figs. 1 and 4, Table 2).

Singlebeam sonar data were acquired along the coast of the Tagliamento delta between the Baseleghe and Lignano inlets, from the Morgo inlet to the Marina Julia beach and in a dense grid in front of the Porto Buso inlet (Figs. 1 and 4, Table 2).

Single-channel seismic and acoustic data were acquired in various surveys (Table 2 and Fig. 4). Interpretation of the geophysical profiles was done by means of the IHS Kingdom ${ }^{\circledR}$ software. We used seismic and acoustic profiles to determine the seafloor depth where singlebeam or multibeam bathymetric data were not acquired. The seismic and acoustic profiles used to create the bathymetric model stretch over a large part of the western part of the gulf, offshore Grado, southeast of Miramare and in the Bay of Muggia (Figs. 1 and 4).

The multibeam and singlebeam sonar data coupled with the interpreted depths of the seafloor from acoustic and seismic profiles were imported in the SKUA-GOCAD ${ }^{\mathrm{TM}}$ Paradigm software package in order to perform quality control and consequent adjustments to the dataset. In order to convert the seismic and acoustic data from the time to the depth domain, $1514 \mathrm{~m} \mathrm{~s}^{-1}$ was assumed as the velocity of sound in the water column. This value represented the average value of sound velocity profiler measurements acquired together with the datasets used in this study. After the conversion gridding of the bathymetric model was done with the discrete smooth interpolation (DSI) method (Mallet, 1992, $1997)$ in the SKUA-GOCAD ${ }^{\mathrm{TM}}$ software package. The coordinates of the pointsets building the model were clipped to the coastline extent and later exported as a column-based text file and a geotiff grid with a $50 \mathrm{~m} \times 50 \mathrm{~m}$ cell size. The resulting model contained some areas with negative depth values that resulted from lack of geophysical data in the near proximity of the coast. In addition, the morphologically very dynamic northern part of the research area starting from the Isonzo mouth towards the west also contained negative depth values due to transient sedimentary bodies elevated above or just below the sea level that were present at the time of

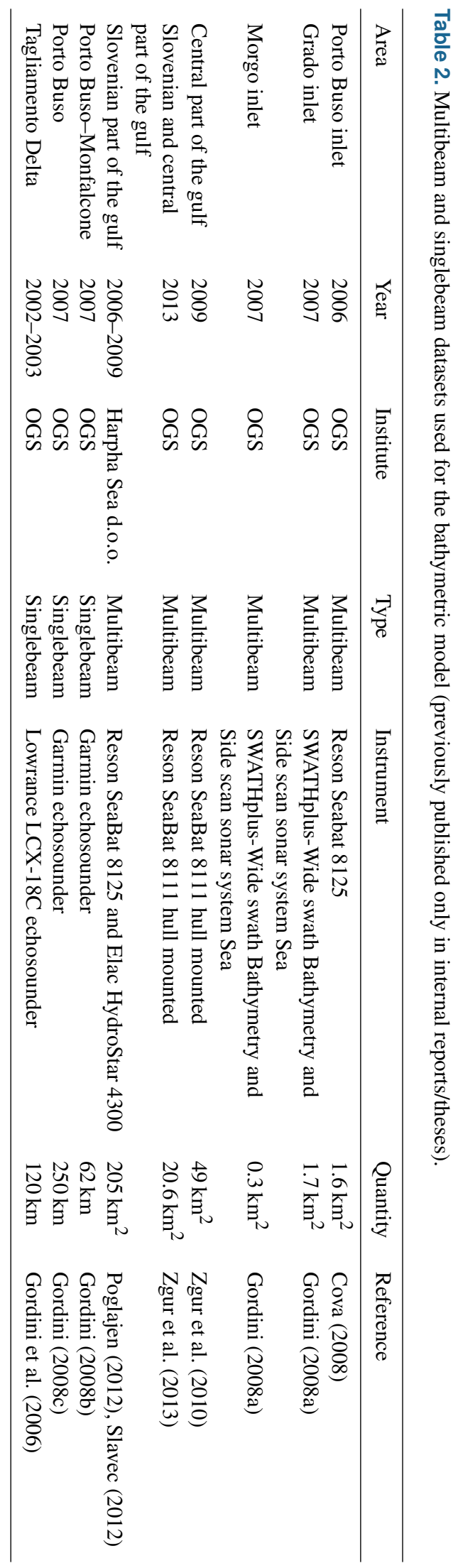

www.earth-syst-sci-data.net/10/1077/2018/ 


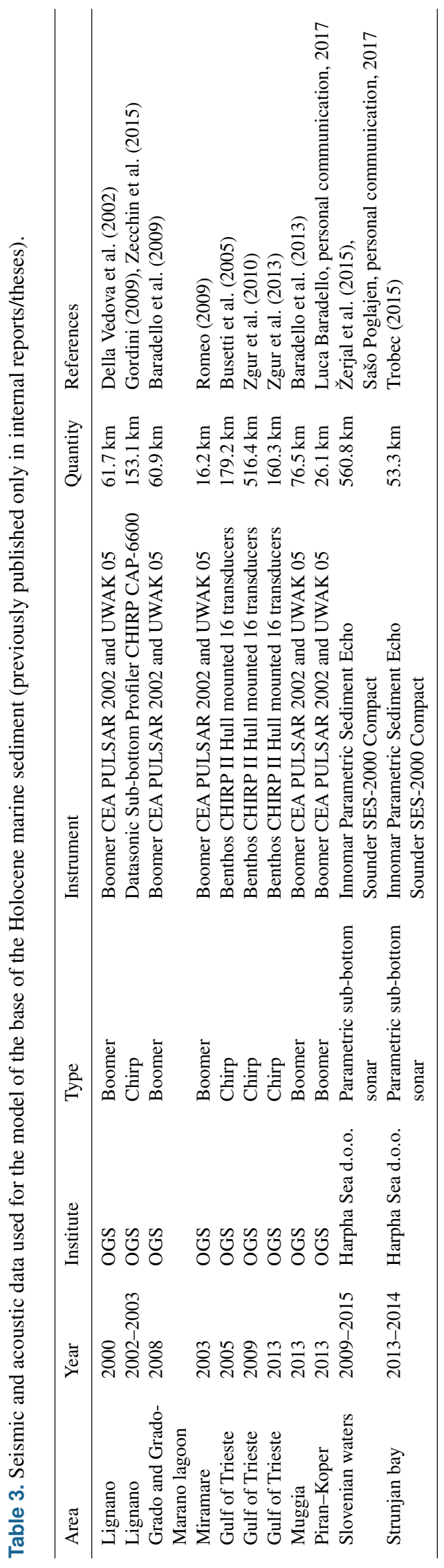

the various surveys but were not delineated by the coastline shapefile used to clip the dataset. In order to still represent these dynamic shallow areas while eliminating artificial negative depths from our dataset, we replaced all the negative values in the geotiff grid and the column-based text file with a depth value of $0.2 \mathrm{~m}$.

\subsection{Model of the base of the Holocene marine sediment}

Seismic (boomer) and acoustic data (Chirp and parametric sub-bottom sonar) were used in order to create a model of the base of the Holocene marine sediment in the Gulf of Trieste (Fig. 5 and Table 3). In general, the used profiles span throughout the Gulf of Trieste but are also located in the inner parts of the Grado Lagoon and Bay of Muggia, and in the Bay of Koper (Fig. 5). The base of the marine Holocene sediment was determined from reflection characteristics visible from profiles that were interpreted by means of the IHS Kingdom ${ }^{\circledR}$ software and calibrated with the cores listed in Table 1. In general, the base of the Holocene marine sediment on geophysical profiles can be recognized as a prominent reflector underlying the acoustically transparent marine sediment (Figs. 3 and 8; Slavec, 2011, 2012; Trobec, 2015; Trobec et al., 2017). Additionally, depths of the base of Holocene marine sediment determined from offshore and onshore well and core data from Italy and Slovenia were included in the model and are shown in Table 1 and Figs. 2 and 5 .

This dataset was imported, quality controlled and adjusted in the SKUA-GOCAD ${ }^{\mathrm{TM}}$ software package. A velocity of $1530 \mathrm{~m} \mathrm{~s}^{-1}$ was assumed for the velocity of sound travelling through the Holocene marine sediment and used for the conversion of seismic and acoustic data from the time to depth domain. Afterwards, gridding of the model of the base of the Holocene was done in the SKUA-GOCAD ${ }^{\mathrm{TM}}$ software package with the DSI method. Even though the sound velocity of the sediment overlying the flysch in the Gulf of Trieste was determined at $1610 \mathrm{~m} \mathrm{~s}^{-1}$ (Masoli et al., 2015), we decided for a lower value because Masoli et al. (2015) considered a Late Pleistocene-Holocene sedimentary sequence a few tens of metres thick where compaction most probably already affected the velocity value. Considering (a) that the typical sound velocity of a marine water saturated sediment is approximately $1500 \mathrm{~m} \mathrm{~s}^{-1}$ (Anderson and Hampton, 1980; Yuan et al., 1992), (b) that the average value of sound velocity profiler measurements acquired together with the datasets used in this study is $1514 \mathrm{~m} \mathrm{~s}^{-1}$, and (c) that the Holocene marine sediment thickness in our study is an order of magnitude smaller than the sediment considered in Masoli et al. (2015) leads us to believe that our chosen velocity is reasonable for our conversion. The coordinates of the pointsets building the model were clipped to the coastline extent and later exported as a column-based text file and a geotiff grid with a $50 \mathrm{~m} \times 50 \mathrm{~m}$ cell size. 


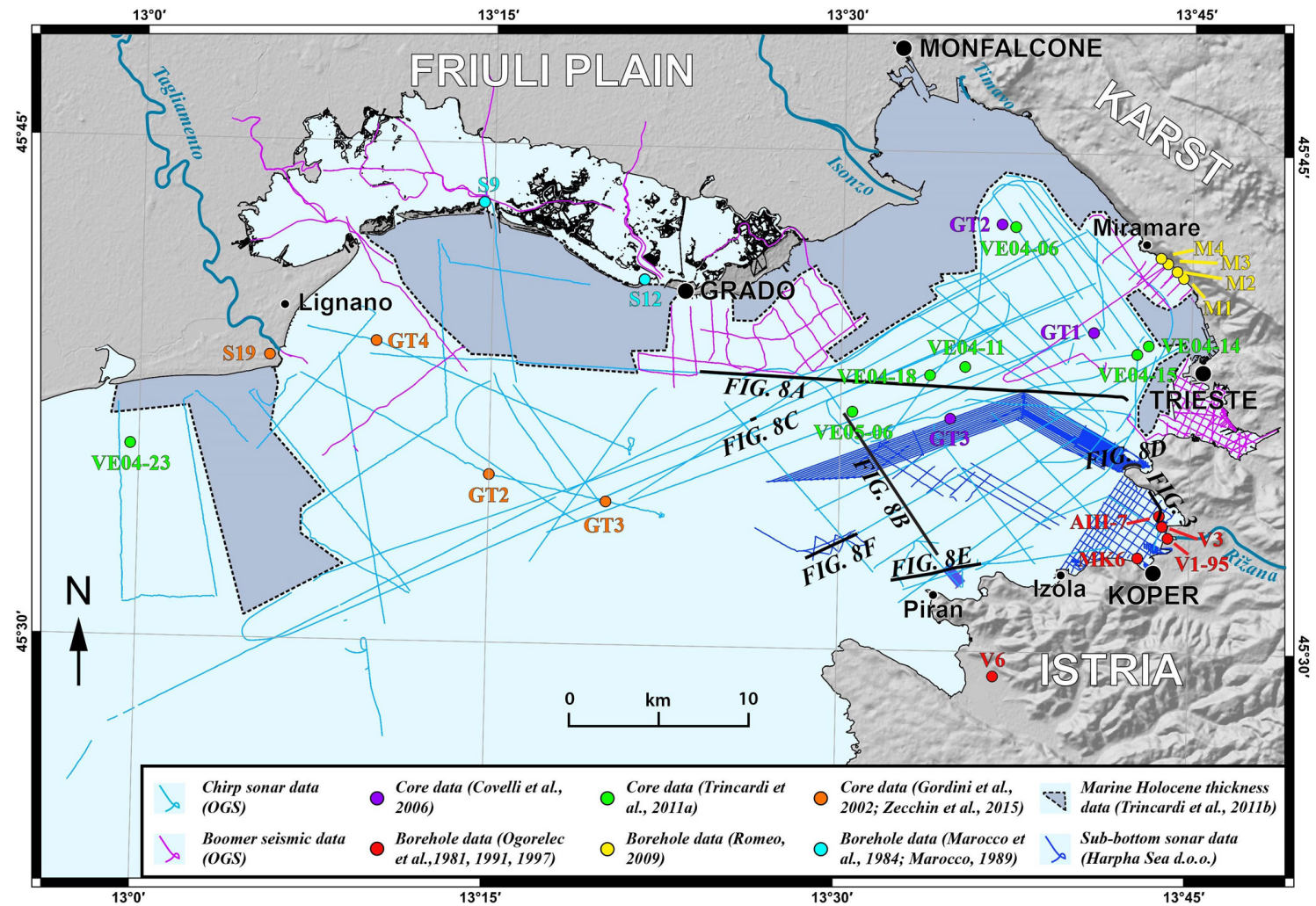

Figure 5. Locations of the datasets used for the model of the base of the Holocene. Black lines indicate locations of acoustic profiles shown in Figs. 3 and 8. Note that the black dashed lines mark areas where published data from Trincardi et al. (2011b) were used for the model of the thickness of Holocene marine sediment.

\subsection{Modelling the thickness of Holocene marine sediment}

A model of the thickness of Holocene marine sediment in the Gulf of Trieste was created with the SKUA-GOCAD ${ }^{\mathrm{TM}}$ software. In order to create the model, the difference between the bathymetric model and the model of the base of the Holocene was calculated. Data used to create the model of the base of the Holocene spanned over a smaller area compared to the bathymetric model (Figs. 4, 5, 6 and 7). In areas where data coverage was insufficient or even absent (grey areas bounded by black dashed lines in Fig. 5), we used data from the Carta degli spessori dei sistemi di stazionamento alto (HST) published by Trincardi et al. (2011b), for which we assumed $1530 \mathrm{~m} \mathrm{~s}^{-1}$ as the velocity of sound travelling through the sediment. We excluded the areas inside the Grado-Marano lagoon from the model due to dubious interpretation of geophysical profiles (signal reverberation) resulting from shallow seafloor depth and because these Holocene sediments were deposited in a lagoonal rather than marine sedimentary environment. The coordinates of the pointsets building the model were clipped to the coastline extent and later exported as a column-based text file and a geotiff grid with a $50 \mathrm{~m} \times 50 \mathrm{~m}$ cell size. The model contained negative thickness values in areas of erosion (e.g. Fig. 8e) and in the west- ern part of the research area, where Holocene marine sediment is very thin or even absent and is therefore very difficult to model. In this area thicker sedimentary sequences can seldom be found only as infill of Late Pleistocene channels (Fig. 8a and c). When modelling such geometries, the base of the Holocene surface tends to rise above the seafloor outside the channel as a convex more or less pronounced bulge. This in turn results in artificial negative thickness values. In order to honour the data, we replaced all the negative values in the geotiff grid and the column-based text file with a thickness value of zero.

\section{Results}

\subsection{Bathymetry of the Gulf of Trieste}

The bathymetry of the seabed of the Gulf of Trieste has a generally smooth morphology. Depth values in our model vary between 0.2 and $32.6 \mathrm{~m}$ below sea level with a mean of $16.2 \mathrm{~m}$ and standard deviation of 6.2 (Fig. 6). In the southeastern and eastern parts of the gulf depth exceeds the $20 \mathrm{~m}$ isobath approximately $4 \mathrm{~km}$ away from the shore at most, while in the northern and northwestern parts the distance needed is approximately twice as much (but can reach up to $20 \mathrm{~km}$ ). 


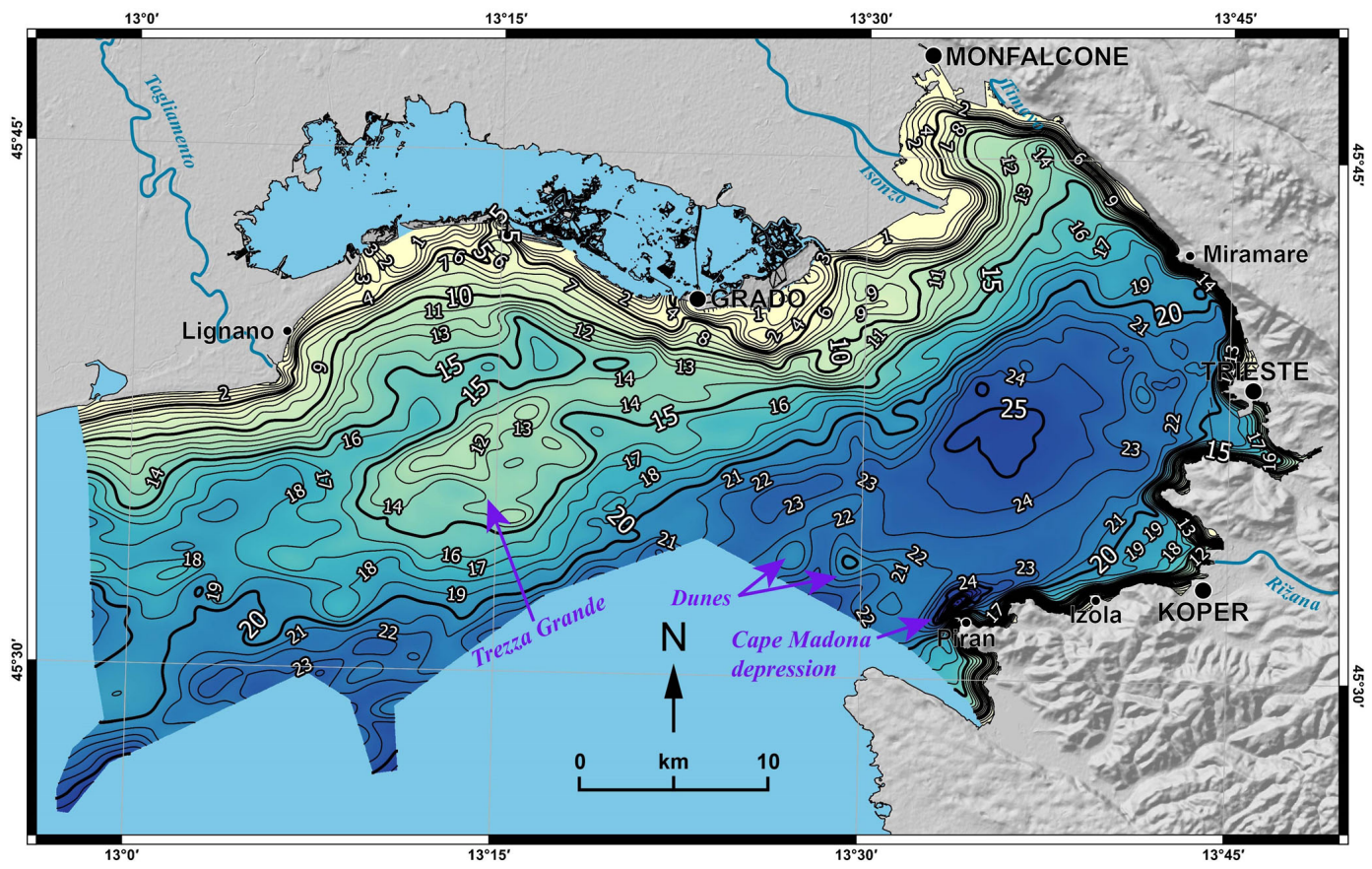

Figure 6. Map of the bathymetry of the Gulf of Trieste (in metres) with prominent morphological features indicated with purple arrows.

The Trezza Grande paleodelta (Gordini et al., 2002; Zecchin et al., 2015) and the dune-shaped features NW of Piran (Slavec, 2012) are topographically higher areas visible in Fig. 6. The deepest feature on the bathymetric model is the elongated Cape Madona depression stretching in a SW-NE direction north of Piran (Fig. 6), which also represents the deepest point of the Gulf of Trieste, with a depth of $38 \mathrm{~m}$ (Ministry of Transport of the Republic of Slovenia, 2005; Slavec, 2012). A deeper area where depths exceed $25 \mathrm{~m}$ is located north of Piran and west of the Bay of Muggia.

\subsection{Base of the Holocene marine sediment}

Contrary to the smoothness of the bathymetric model, the model of the base of the Holocene marine sediment presents rougher morphologies (Fig. 7), which are evident also from Figs. 3 and 8. The model of the base of the Holocene is located between 6.6 and $31.0 \mathrm{~m}$ below sea level with a mean of $19.8 \mathrm{~m}$ and a standard deviation of 5.7. In general, the model can be divided into two parts, the shallower northwestern part and the deeper southeastern part (Fig. 7). This difference in depth is also evident from geophysical profiles (Fig. 8a and b) and core data (Fig. 2).

The northwestern part is shallower than $20 \mathrm{~m}$ and in general rises as we approach the coastline. Local topographical highs are located in the southern part of the Trezza Grande area (Fig. 7). In places the model exhibits channel-like features that are a few metres deeper than the surrounding topography, but their exact course is difficult to map due to insufficient profile coverage.
The base of Holocene marine sediment in the southeastern part of the gulf forms a basin that is in general deeper than $25 \mathrm{~m}$ below sea level (Fig. 7) and is also visible in geophysical profiles and recognizable in core data (Figs. 8 and 2). Shallower depths can only be observed in the Bay of Muggia and in the immediate vicinity of the coastline where it rises rapidly in a very short distance (Fig. 7). A slightly deeper section oriented in a WNW-ESE direction approximately $6 \mathrm{~km}$ north of Piran is evident and corresponds to the meander belt of the Paleorižana (Slavec, 2012; Trobec et al., 2017).

\subsection{Thickness of Holocene marine sediment}

The modelled thickness of the Holocene marine sediment in the Gulf of Trieste ranges between 0 and $24.0 \mathrm{~m}$ with a mean thickness of $3.2 \mathrm{~m}$ and a standard deviation of 2.8. In general, the inner parts of the gulf are covered by very thin drapes of Holocene marine sediment that can also be partially absent (Figs. 9, 8a and b). Towards the shore, the Holocene sedimentary sequence gradually thickens and appears as a coastal sedimentary wedge that can exceed thicknesses of $10 \mathrm{~m}$ near the coastline and in the internal parts of bays.

The map of the thickness of the Holocene marine sediment in the Gulf of Trieste can be divided into two parts, the central-western part with thinner marine sequences and the southeastern part of the gulf with thicker Holocene marine sediments (Fig. 9). This prominent difference is clearly evident from geophysical profiles spanning through a larger part of the gulf (Fig. 8a and b) and from a simplified W-E stratigraphic profile from the published cores (Fig. 2). 


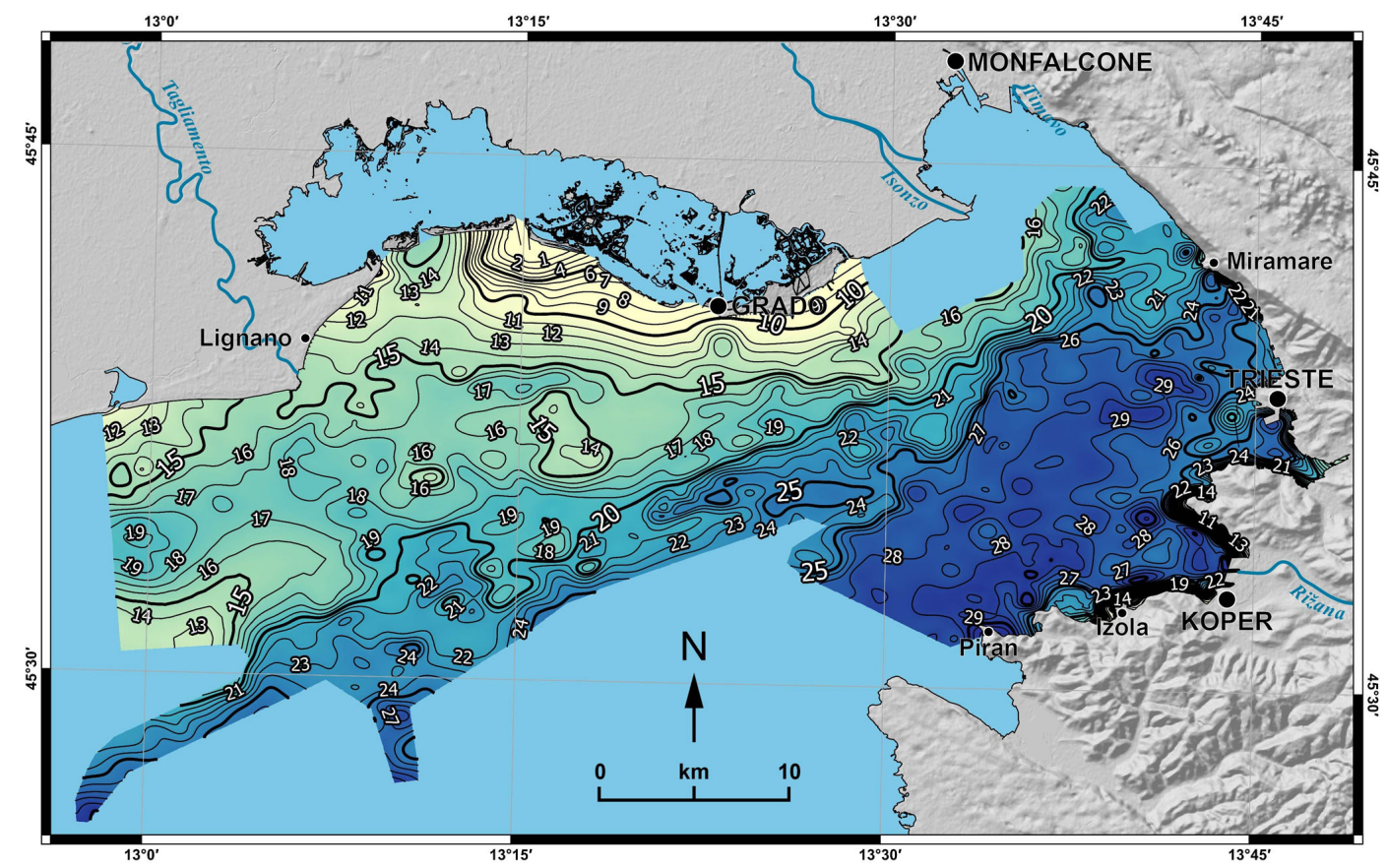

Figure 7. Map of the depth of the base of the Holocene marine sediment in metres.

The central-western part of the gulf is characterized by a very thin Holocene sedimentary cover which rarely exceeds a thickness of $3 \mathrm{~m}$ (Figs. 9, 8a and b). Where the thin sediments are not well resolved or even unresolvable with the highresolution geophysical methods used in this study, we assume they are absent or only a few centimetres thick. Thicker Holocene sedimentary sequences can be observed only in the vicinity of the Tagliamento delta (Figs. 9, 3 and 4 from Zecchin et al., 2015), the Trezza Grande paleodelta (Figs. 2 and 9; Figs. 4 and 5 from Zecchin et al., 2015) and in the central part of the bay where thicker sedimentary sequences fill pre-Holocene paleochannels (Figs. 9, 7, 8a, b and c).

The southeastern part of the gulf is characterized by a thicker sedimentary cover which averages at about $5 \mathrm{~m}$ (Figs. 9, 2, 8a and b). Further examination reveals that in some places in close proximity to the shoreline the Holocene sedimentary cover often thins out or is unresolvable in geophysical profiles (for example near Debeli rtič, Fig. 8d). This effect is a consequence of basement rock (predominantly flysch) outcropping and/or subcropping near the seafloor. In the Cape Madona depression in front of Piran (Fig. 6) the marine Holocene sedimentary sequence is not recognizable due to erosion which can also be identified on geophysical profiles down to the Late Pleistocene sediment (Fig. 8e). In addition to thick marine Holocene sedimentary deposits in the internal parts of bays (Figs. 9 and 2), thicker sedimentary sequences can be observed over buried paleochannels (Figs. 9, 8a, b and c; Slavec, 2012; Trobec, 2015, Trobec et al., 2017) and in the area of the dune-shaped features NW of Piran (Figs. 6, $8 f$ and 9).

\section{Model quality assessment}

While our work was done with great care and attention to detail in order to produce accurate results, we would like to emphasize that the model is primarily intended to illustrate the general trend of the thickness of Holocene marine sediment in the Gulf of Trieste and cannot account for strong local thickness variations. This is a result of several factors that are described in the following section.

As mentioned in Sects. 3.2 and 3.3, the surface of the base of the Holocene marine sediment can be very undulated due to the pre-existing paleotopography and/or due to subcropping or outcropping of the basement rock on the seafloor near the eastern and southern coastlines (Fig. 8d). Combined with areas where density of acoustic and seismic profiles is not adequate, this undulation can lead to artefacts that are later outstretched throughout the model of the base of the Holocene and consequentially affect the values of the model of the thickness. Discrepancies of the map with the natural state are also a result of the gridding algorithm used (Mallet, 1992, 1997). Due to the inherent two-way travel time attribute of the acquired data in the case of geophysical profiles, major influencing factors on the models are the chosen velocity for the conversion to the time domain and the local sound velocity variations in the Holocene sediment which are unknown. As there are no measurements of speed of sound travelling solely through the Holocene sediment of the Gulf of Trieste, we used a conservative approximation of the speed of sound travelling through the sedimentary column, which could lead to systematic underestimation of the 

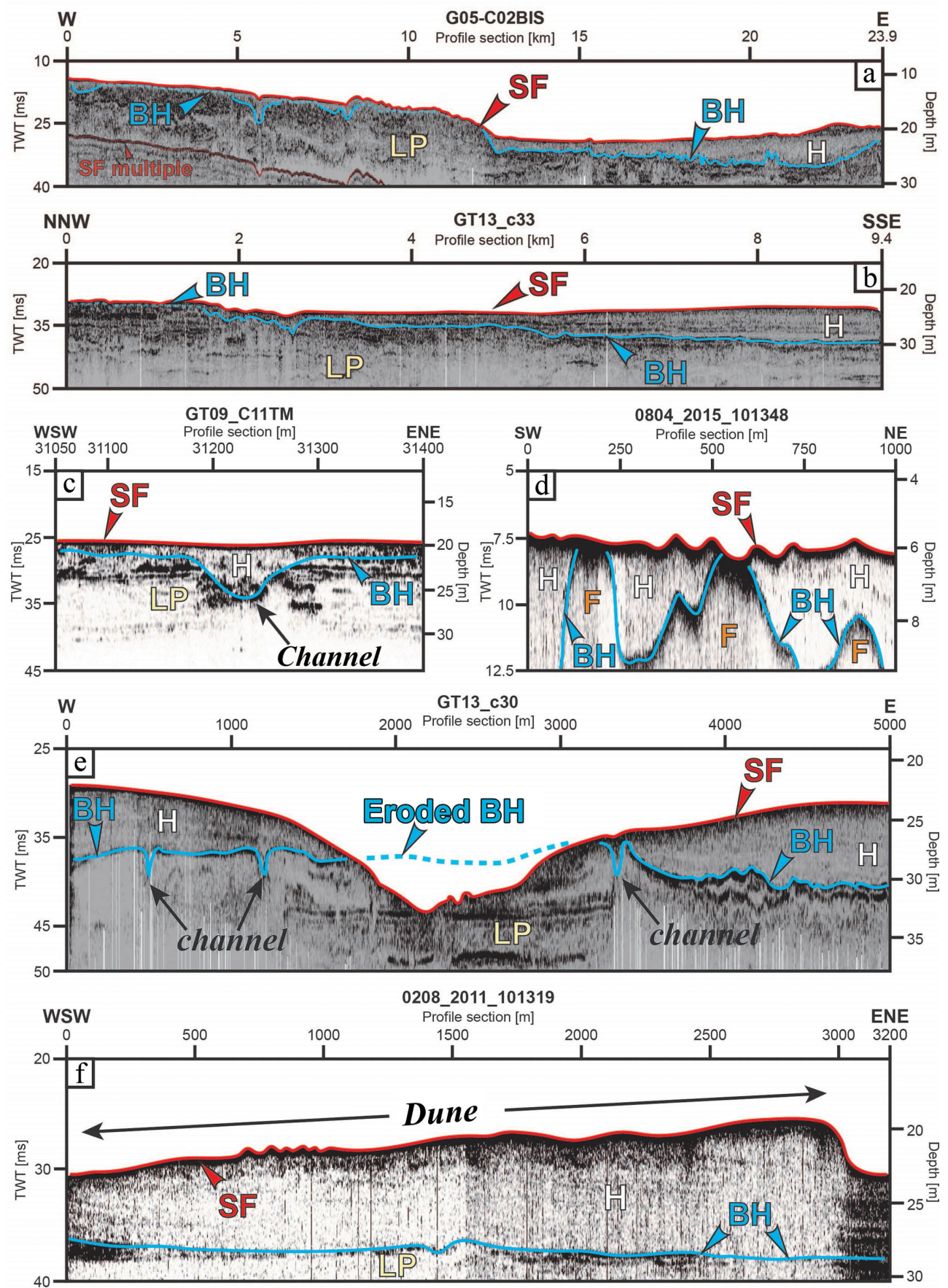

Figure 8. Examples of sub-bottom and Chirp sonar profiles (for explanation of the symbols, refer to the caption of Fig. 3); (a-b) regional Chirp profiles show that the Late Pleistocene paleotopography forms a basin in the eastern part which serves as a depocentre for the Holocene marine sediment (dashed blue line - base of the Holocene sediment where the sedimentary sequence is very thin or even absent or eroded); (a) a W-E oriented profile showing a difference in marine Holocene thickness in the western and eastern parts of the gulf. Note that thicker Holocene marine sequences in the western part of the gulf are filling channel-like features; (b) a NNW-SSE oriented profile showing the same difference in Holocene marine thickness; $(\mathbf{c}-\mathbf{f})$ variations of the thickness of marine Holocene sediment; (c) a profile from the central part of the gulf, where a thin Holocene marine sediment cover is characteristic, except where it fills pre-existing channels; (d) variation of Holocene sediment thickness controlled by the pre-existing Flysch paleotopography in the area of Debeli rtič; (e) Holocene sediment erosion in the seafloor depression in front of Piran (Fig. 6); note also Holocene filling of pre-existing channels; (f) thicker Holocene sedimentary sequences visible on a profile crossing the area of dunes in front of Piran (Fig. 6). For locations of the profiles, see Fig. 5. 


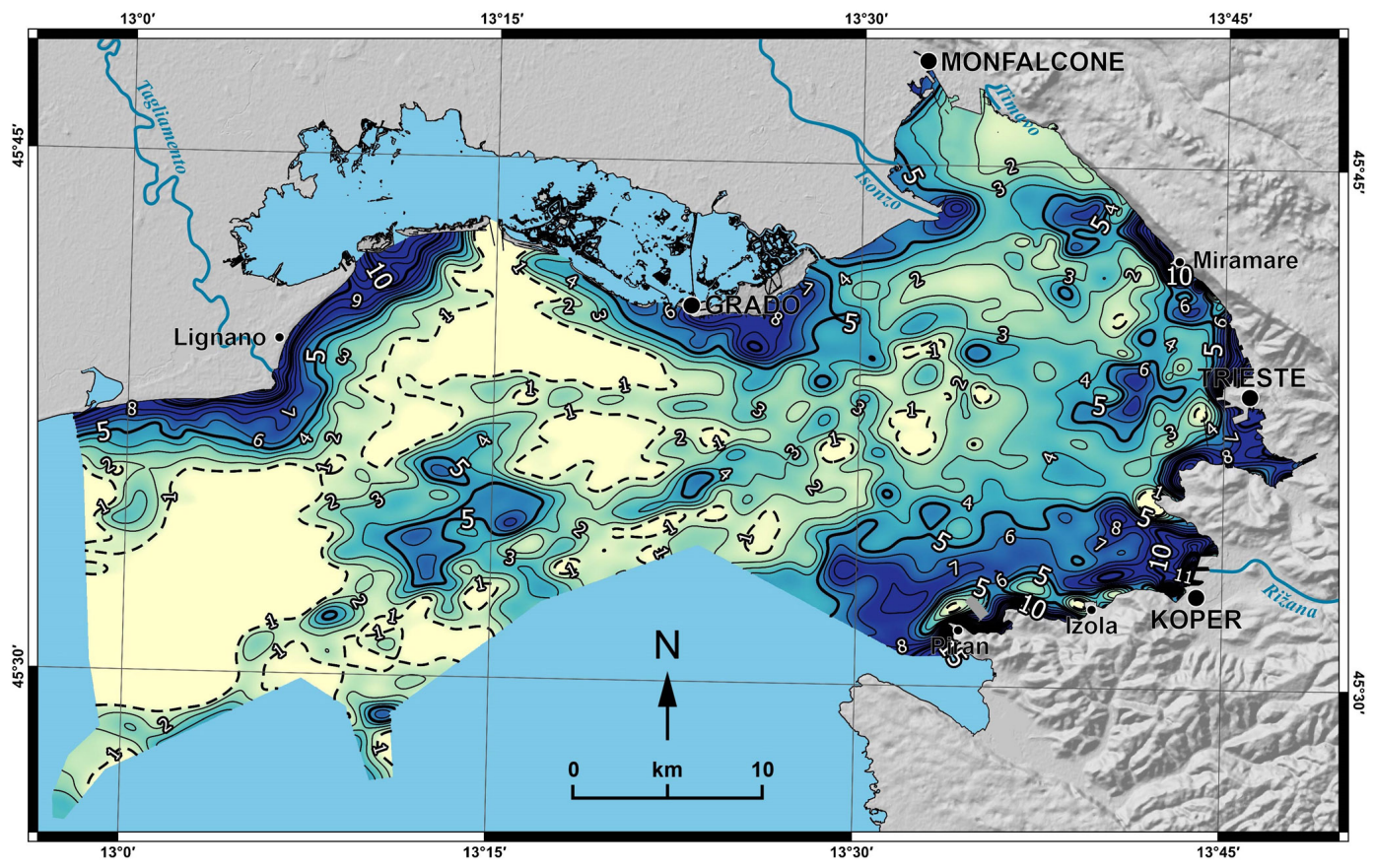

Figure 9. Map of the thickness of the Holocene marine sediment in metres. Dashed black lines mark areas where Holocene marine sediment is thinner than $1 \mathrm{~m}$ or even absent.

thickness throughout the whole study area. Due to a lack of sound velocity measurements we also assumed a model without velocity variations. Finally, due to scarce cores/wells, the presence of marine sediment in the Holocene sedimentary sequence was assessed mostly by following visual criteria when investigating geophysical profiles. We considered the acoustically transparent Holocene seismic facies to represent sediment primarily deposited in a marine environment. In order to avoid including predominantly paralic Holocene sediment in the model, we excluded the Grado-Marano lagoon area from the model of the thickness of Holocene marine sediment.

The first opportunity to test the quality of our model was presented by two $1.5 \mathrm{~m}$ long cores composed entirely of Holocene marine sediment (Mautner et al., 2018; Tomašových et al., 2017) that were published after the creation of our dataset. The cores M28 and M53 were collected in the Bay of Panzano and NW of Piran. In both locations the modelled thicknesses of the Holocene marine sequence exceed $1.5 \mathrm{~m}$, which demonstrates the quality of our model and the potential of our dataset for planning of future core collecting campaigns.

\section{Data availability}

An important moment of the data lifecycle is that when observations are shared with other team members or domain experts in general. This introduces the possibility of replicating the experiment, of re-using the data in other contexts, and of providing data with additional value. OGS is deeply involved in the curation and dissemination of its data assets and has in this perspective developed a web-based data system called SNAP (Diviacco et al., 2015; Diviacco and Busato, 2013) which allows the contained data to be findable, accessible, interoperable and reusable (FAIR). The system is based on fully compliant OGC O\&M and SensorML metadata and offers previewing facilities that allow remote data access and download once the end user has checked whether they are what he/she is looking for. DOIs are assigned to the datasets residing in the system so that they can be directly accessed resolving the DOIs or simply following the corresponding URLs. In the case of the models used in this study, they are accessible at the following URL: http://doi.org/cpz2. This points to a landing page which has been built following the standards set in the UNESCO Ocean data Publication Cookbook (Leadbetter et al., 2013), and offers further metadata details and an interactive preview of the dataset.

The data described in this study (Trobec and Busetti, 2017) are available as column-based text files containing data points with $X, Y$ and $Z /$ thickness coordinates in the UTM 33 North coordinate system (datum: WGS 84). In order to facilitate their use (especially with GIS software) these datasets are also available as $50 \times 50 \mathrm{~m}$ elevation grids clipped to the extent of the coastline in the widely compatible geotiff format along with georeferencing information (the *.proj and *.tfw files). Depth contours of the models are also available in the shapefile format. 


\section{Conclusions}

Together with the published datasets (http://doi.org/cpz2), this paper represents the second assessment of the thickness of Holocene marine sediment in a major part of the Gulf of Trieste, employing new datasets from a wide range of different geophysical methods and published sedimentological data from wells and cores.

Geophysical profiles along with core/well data show a basin in the Late Pleistocene topography in the southeastern part of the gulf that served as a depocentre for the significantly thicker Holocene marine sedimentary sequences compared to the rest of the gulf. While the exact cause of the basin formation exceeds the scope of this paper, we suspect it represents an interplay between different tectonic, sedimentologic, climatic and oceanographic factors that need to be further examined in order to better understand the distribution of Holocene marine sediment in the Gulf of Trieste. Additionally, thicker Holocene marine sequences can be observed above paleochannels, in the Trezza Grande area and in the internal parts of bays and in close proximity to the shoreline, where the thickness is probably governed by increased amounts of available sediment transported by rivers and surface run-off from rocky coasts of the southeastern part and due to increased amounts of fluvially transported sediment from the alluvial plains of the northern and northwestern coasts of the gulf (Covelli et al., 2004; Ogorelec et al., 1991; Mandac Soczka and Faganeli, 2015). In the central part of the gulf the Holocene marine sequences are very thin or even absent (unresolvable on geophysical profiles).

Our work provides a solid reference for a wide variety of disciplines involved in future studies of Holocene sediment in the area, especially regarding sampling sites and/or survey selection. Furthermore, the thickness model provides important implications for further sedimentological, geomorphological, paleoenvironmental, neotectonic and oceanographic studies of the Gulf of Trieste.

Author contributions. AT interpreted acoustic data from the Slovenian part of the gulf, modelled the surfaces and thickness, prepared the figures and wrote the manuscript. MB conceived and managed the study, interpreted the geophysical data from the Italian part of the gulf and contributed in writing the manuscript. FZ, LB, AC, EG, RR and IT acquired the multibeam, singlebeam and sonar data in various campaigns in the Italian part of the gulf. $A B$, EG and RR interpreted various geophysical datasets in the Italian part. LB, EG, IT and FZ processed the geophysical data from the Italian part. SP acquired and processed the multibeam dataset and the sub-bottom sonar profiles from the Slovenian part of the gulf. PD managed data and metadata handling on the online repository. MV interpreted acoustic data from the Slovenian part of the gulf.

Competing interests. The authors declare that they have no conflict of interest.
Acknowledgements. Figures in the paper were produced using Copernicus digital elevation model data and information funded by the European Union - EU-DEM layers. A substantial part of this work was conducted during an Erasmus+ internship of the first author (SMP-2014-2015-3307) at the Istituto Nazionale di Oceanografia e di Geofisica Sperimentale (OGS). Additionally, we would like to acknowledge the Slovenian Research Agency for the Young Researcher grant of the first author (1000-15-0510-6/15). We would also like to acknowledge IHS Kingdom for their Educational grant which allowed us to use the Kingdom software.

The data used in this work were acquired during several projects. The authors acknowledge project "Mapping of the regional geothermal resource and guidelines for the use" supported by the Geological Service of the Autonomous Region of Friuli Venezia Giulia from 2004 to 2006, Italian FISR project VECTOR from 2006 to 2010, OGS project "Gulf of Trieste" in 2009, service activity "Survey in the SIN Site of Trieste, the Muggia Bay" for the Multiproject srl of Gorizia (Italy) in 2013, project "SLOMARTEC" of OGS, the Department of Geology (University of Ljubljana) and Harpha Sea d.o.o. in 2013, project "Application of sonar in research of active tectonics and paleoseismology in low-strain environments" (L15452) supported by the Slovenian Research Agency and Harpha Sea d.o.o. from 2013 to 2016 and the "Preliminary survey for submarine cable interconnection between Italy and Slovenia" service for Next Geosolutions Europe SpA in 2015.

We would like to acknowledge the reviewer comments suggested by Thomas M. Cronin and Cristina Bernardes. Their input along with the comments provided by Adam Tomašových allowed us to further improve our manuscript.

Edited by: David Carlson

Reviewed by: Thomas M. Cronin and Cristina Bernardes

\section{References}

Anderson, A. L. and Hampton, L. D.: Acoustics of gas-bearing sediments I. Background, J. Acoust. Soc. Am., 67, 1865-1889, https://doi.org/10.1121/1.384453, 1980.

Baradello, L., Busetti, M., and Visnovich, G.: Progetto VECTOR: Rilievo sismico ad alta risoluzione nella Laguna di Grado e Marano, Rep. 8443, Rep. 2009/89 GDL 39 GEBA, Istituto Nazionale di Oceanografia e di Geofisica Sperimentale - OGS, Sgonico, Italy, 16 pp., 2009.

Baradello, L., Busetti, M., Nieto, D., Romeo, R., and Visnovic, G.: Survey VHR Sismico Boomer del Sito di Interesse Nazionale (SIN) di Trieste, Rep. OGS 2013/14 - IRI 2, Istituto Nazionale di Oceanografia e di Geofisica Sperimentale - OGS, Sgonico, Italy, 29 pp. and 33 att., 2013.

Biolchi, S., Furlani, S., Covelli, S., Busetti, M., and Cucchi, F.: Morphoneotectonics and lithology of the eastern sector of the Gulf of Trieste (NE Italy), J. Maps, 12, 936-946, https://doi.org/10.1080/17445647.2015.1099572, 2016.

Busetti, M., Cova, A., Marchi, M., Romeo, R., Volpi, V., and Zgur, F.: Realizzazione della carta geologico-tecnica della risorsa geotermica regionale, Rep. 80/2005 - RIMA 9, 47 pp. and 5 att., 2005.

Busetti, M., Volpi, V., Nicolich, R., Barison, E., Romeo, R., Baradello, L., Brancatelli, G., Giustiniani, M., Marchi, M., Zanolla, 
C., Wardell, N., Nieto, D., and Ramella, R.: Dinaric tectonic features in the Gulf of Trieste (Northern Adriatic Sea), Bollettino di Geofisica Teorica ed Applicata, 51, 117-128, 2010a.

Busetti, M., Volpi, V., Barison, E., Giustiniani, M., Marchi, M., Ramella, R., Wardell, N., and Zanolla, C.: Meso-Cenozoic seismic stratigraphy and the tectonic setting of the Gulf of Trieste (northern Adriatic), GeoActa, SP 3, 1-14, 2010 b.

Carulli, G. B.: Structural model of the Trieste Gulf: A proposal, J. Geodynam., 51, 156-165, https://doi.org/10.1016/j.jog.2010.05.004, 2011.

Carulli, G. B., Podda, F., Venturini, C., Zanferrari, A., Cucchi, F., Monegato, G., Nicolich, R., Paiero, G., Piano, C., Slejko, D., Tunis, G., Zanolla, C., Bartolini, C., Masetti, D., Ponton, M., Stefani, C., Zini, L., Burelli, G., and Marchesini, A.: Carta Geologica del Friuli Venezia Giulia, Scale: 1 : 150000, Regione Autonoma Friuli Venezia Giulia, Direzione Centrale Ambiente e Lavori Pubblici, Servizio Geologico, Trieste, Italy, 2006.

Cimolino, A., Della Vedova, B., Nicolich, R., Barison, E., and Brancatelli, G.: New evidence of the outer Dinaric deformation front in the Grado area (NE-Italy), Rend. Fis. Acc. Lincei, 21, 167179, https://doi.org/10.1007/s12210-010-0096-y, 2010.

Cova, A.: Progetto VECTOR: Acquisizione dati multibeam nella bocca lagunare di Porto Buso (Laguna di Grado e Marano), Rep. 2008/40 - RIMA 4 ADAM, Istituto Nazionale di Oceanografia e di Geofisica Sperimentale - OGS, Sgonico, Italy, 20 pp., 2008.

Covelli, S., Piani, R., Faganeli, J., and Brambati, A.: Circulation and suspended matter distribution in a microtidal deltaic system: The Isonzo river mouth (northern Adriatic Sea), J. Coastal Res., 41, 130-140, 2004.

Covelli, S., Fontolan, G., Faganeli, J., and Ogrinc, N.: Anthropogenic markers in the Holocene stratigraphic sequence of the Gulf of Trieste (northern Adriatic Sea), Mar. Geol., 230, 29-51, https://doi.org/10.1016/j.margeo.2006.03.013, 2006.

Della Vedova, B., Brancolini, G., Bongiovanni, S., Brusadin, A., Busetti, M., Codermatz, R., Giustiniani, M., Nicolich, R., Paganini, P., and Paoli G.: Studio preliminare degli acquiferi profondi della Pianura friulana, Agreement with the Autonomous Region Friuli Venezia Giulia dd. 09/12/1999, Rep. 7170, Final Report, 54 pp. and 8 thematic maps, 2002.

Diviacco, P. and Busato, A.: The Geo-Seas Seismic data viewer: a Tool to facilitate the control of data access, Bollettino di Geofisica Teorica e Applicata, 54, 257-270, https://doi.org/10.4430/bgta0078, 2013.

Diviacco, P., Wardell, N., Forlin, E., Sauli, C., Burca, M., Busato, A., Centonze, J., and Pelos, C.: Data rescue to extend the value of vintage seismic data: The OGS-SNAP experience, GeoResJ, 6, 44-52, https://doi.org/10.1016/j.grj.2015.01.006, 2015.

EMODnet: Map Viewer, Sea-floor Geology (Tectonic lines), available at http://www.emodnet-geology.eu/map-viewer/, last access: 12 June 2018.

Faganeli, J., Planinc, R., Pezdič, J., Smodiš, B., Stegnar, P., and Ogorelec, B.: Marine geology of the Gulf of Trieste (northern Adriatic): Geochemical aspects, Mar. Geol., 99, 93-108, https://doi.org/10.1016/0025-3227(91)90085-I, 1991.

Gordini, E.: Evolutionary trends in the beaches of the Tagliamento river delta, Bollettino di Geofisica Teorica e Applicata, 48, 287304, 2007.

Gordini, E.: Progetto VECTOR Rilievo mutlibeam delle bocche laguanri di Grado e Morgo (Laguna di Grado e Marano) re- alizzato con sistema interferometrico swathplus wide swath bathymetry \& side scan sonar system, Rep. 119/2008 - RIMA 24 GEA, Istituto Nazionale di Oceanografia e di Geofisica Sperimentale - OGS, Sgonico, Italy, 38 pp., 2008a.

Gordini, E.: Progetto VECTOR: Rilievo batimetrico singlebeam dell'Area marina-litorale della Regione Friuli Venezia Giulia, Report 118/2008 RIMA 22 GEA, Istituto Nazionale di Oceanografia e di Geofisica Sperimentale - OGS, Sgonico, Italy, 53 pp., 2008 b.

Gordini, E.: Progetto VECTOR: Rilievo batimetrico singlebeam dell' ebb-tidal delta di Porto Buso, Report 117/2008 RIMA 22 GEA, Istituto Nazionale di Oceanografia e di Geofisica Sperimentale - OGS, Sgonico, Italy, 37 pp., 2008c.

Gordini, E.: Integrazione di metodologie geofisiche, geomorfologiche, sedimentologiche e geochimice, per la definizione della genesi e dell'età degli affioramenti rocciosi presenti sul fondale marino dell' Adriatico settentrionale, $\mathrm{PhD}$ thesis, University of Trieste, Trieste, Italy, 363 pp., 2009.

Gordini, E., Marocco, R., and Vio, E.: Stratigrafia del sottosuolo della "Trezza Grande" (Golfo di Trieste, Adriatico Settentrionale), Gortania, 24, 31-63, 2002.

Gordini, E., Caressa, S., and Marocco, R.: Nuova carta morfosedimentologica del Golfo di Trieste (da Punta Tagliamento alla Foce dell'Isonzo), Gortania, 25, 5-29, 2003.

Gordini, E., Marocco, R., Tunis, G., and Ramella, R.: I depositi cementati del Golfo di Trieste (Adriatico Settentrionale): Distribuzione areale, caratteri geomorfologici e indagini acustiche ad alta risoluzione, Il Quaternario, 17, 555-563, 2004.

Gordini, E., Marocco, R., and Ramella, R.: Dinamica morfologica del litorale del delta del fiume Tagliamento (Adriatico settentrionale) in relazione ai possibili interventi di ripascimento, Il Quaternario, 19, 45-65, 2006.

Istituto Idrografico della Marina: Carta nautica Da Punta Tagliamento a Pula 1:100 000, 2004.

Jurkovšek, B., Biolchi, S., Furlani, S., Kolar-Jurkovšek, T., Zini, L., Jež, J., Tunis, G., Bavec, M., and Cucchi, F.: Geology of the Classical Karst Region (SW Slovenia-NE Italy), J. Maps, 12, 352362, https://doi.org/10.1080/17445647.2016.1215941, 2016.

Kolega, N. and Poklar, M.: Morphological analysis of the Slovenian coast with data from lidar and sonar ranging, Acta Geogr. Slov., 52, 121-140, https://doi.org/10.3986/AGS52105, 2012.

Lambeck, K., Antonioli, F., Purcell, A., and Silenzi, S.: Sea-level change along the Italian coast for the past 10,000 yr, Quaternary Sci. Rev., 23, 1567-1598, https://doi.org/10.1016/j.quascirev.2004.02.009, 2004.

Leadbetter, A., Raymond, L., Chandler, C., Pikula, L., Pissierssens, P., and Urban, E.: Ocean Data Publication Cookbook, Executive Summary, Intergovernmental Oceanographic Commission, Unesco, Paris, IOC Manuals and Guides 64, 2013.

Mallet, J. L.: Discrete smooth interpolation in geometric modelling, Comput. Des., 24, 178-191, https://doi.org/10.1016/00104485(92)90054-E, 1992.

Mallet, J. L.: Discrete modeling for natural objects, Math. Geol., 29, 199-219, https://doi.org/10.1007/BF02769628, 1997.

Mandac Soczka, R. and Faganeli, J.: Deposition of riverine suspended solids in a shallow bay (Bay of Koper, Gulf of Trieste, northern Adriatic Sea), J. Soils Sediments, 15, 2433-2442, https://doi.org/10.1007/s11368-015-1146-y, 2015. 
Marocco, R.: Evoluzione quaternaria della Laguna di Marano (Friuli-Venezia Giulia), Il Quaternario, 2, 125-137, 1989.

Marocco, R.: Evoluzione tardopleistocenica-olocenica del delta del F. Tagliamento e delle Lagune di Marano e Grado (Golfo di Trieste), Il Quaternario, 1b, 223-232, 1991.

Marocco, R., Pugliese, N., and Stolfa, D.: Some remarks on the origin and evolution of the Grado lagoon (Northern Adriatic Sea), Bollettino di Oceanologia Teorica ed Applicata, 2, 11-17, 1984.

Masoli, C. A., Petronio, L., Gordini, E., Deponte, M., Cotterle, D., Romeo, R., Böhm, G., Barbagallo, A., Belletti, R., Maffione, S., and Meneghini, F.: Marine geophysical and geological investigations in support to the construction of new harbour infrastructures: the Trieste Marine Terminal extension, in Atti del 34 convegno nazionale del Gruppo Nazionale di Geofisica della Terra Solida (GNGTS), tema 3: Geofisica Applicata, edited by: Slejko, D., Riggio, A., Rebez, A., Caielli, G., Cassiani, G., Florio, G., Mazzucchelli, P., Nicolich, R., and Sambuelli, L., Istituto Nazionale di Oceanografia e di Geofisica Sperimentale, Trieste, 63-70, 2015.

Mautner, A. K., Gallmetzer, I., Haselmair, A., Schnedl, S. M., Tomašových, A., and Zuschin, M.: Holocene ecosystem shifts and human-induced loss of Arca and Ostrea shell beds in the north-eastern Adriatic Sea, Mar. Pollut. Bull., 126, 19-30, https://doi.org/10.1016/j.marpolbul.2017.10.084, 2018.

Ministry of Transport of the Republic of Slovenia: Male karte Tržaški zaliv Merilo 1 : 100000, 2005.

Ogorelec, B., Mišič, M., Šercelj, A., Cimerman, F., Faganeli, J., and Stegnar, P.: Sediment sečoveljske soline, Geologija, 24, 180-216, 1981.

Ogorelec, B., Mišič, M., and Faganeli, J.: Marine geology of the Gulf of Trieste (northern Adriatic): Sedimentological aspects, Mar. Geol., 99, 79-92, https://doi.org/10.1016/00253227(91)90084-H, 1991.

Ogorelec, B., Faganeli, J., Mišič, M., and Čermelj, B.: Reconstruction of paleoenvironment in the Bay of Koper (Gulf of Trieste, Northern Adriatic), Annales, 11, 187-200, 1997.

Ogrinc, N., Faganeli, J., Ogorelec, B., and Čermelj, B.: The origin of organic matter in Holocene sediments in the Bay of Koper (Gulf of Trieste, northern Adriatic Sea), Geologija, 50, 179-187, https://doi.org/10.5474/geologija.2007.014, 2007.

Placer, L.: Simplified structural map of Kras Kras (Slovene), Carso (Italian) $=$ Geographical unit, Geologija, 58, 89-93, https://doi.org/10.5474/geologija.2015.008, 2015.

Placer, L., Vrabec, M., and Celarc, B.: The bases for understanding of the NW Dinarides and Istria Peninsula tectonics, Geologija, 53, 55-86, https://doi.org/10.5474/geologija.2010.005, 2010.

Pleničar, M., Polšak, A., and Šikić, D.: Osnovna geološka karta SFRJ. / L 33-88, Trst, 1969.

Poglajen, S.: 3D-karta morskega dna slovenskega morja in njena uporaba v geoprostorski podpori pomorstvu Slovenske vojske, in: Geoprostorska podpora obrambnemu sistemu Republike Slovenije, edited by: Balas, J., Kokalj, A., and Kovič, B., Ministrstvo za obrambo Republike Slovenije, Direktorat za obrambne zadeve, Sektor za načrtovanje, Inštitu za antropološke in prostorske študije ZRC SAZU, Geodetski inštitut Slovenije, Ljubljana, Slovenia, 93-106, 2012.

Romeo, R.: Studio geofisico integrato ad alta risoluzione dei depositi marini e della struttura del substrato della Riviera di Mi- ramare (Golfo di Trieste), $\mathrm{PhD}$ thesis, University of Trieste, Trieste, Italy, 175 pp., 2009.

Slavec, P.: Spreminjanje višine morske gladine v kvartarju, Geografski vestnik, 83, 43-56, 2011.

Slavec, P.: Analiza morfologije morskega dna slovenskega morja, MS thesis, University of Ljubljana, Ljubljana, Slovenia, 58 pp. 2012.

Tomašových, A., Gallmetzer, I., Haselmair, A., Kaufman, D. S., Vidović, J., and Zuschin, M.: Stratigraphic unmixing reveals repeated hypoxia events over the past $500 \mathrm{yr}$ in the northern Adriatic Sea, Geology, 45, 363-366, https://doi.org/10.1130/G38676.1, 2017.

Trincardi, F., Correggiari, A., Cattaneo, A., Remia, A., Taviani, M., Angeletti, L., Foglini, F., and Campiani, E.: Carta Geologica dei mari italiani alla scala 1:250.000 foglio NL 33-7 Venezia, Istituto Superiore per la Protezione e la Ricerca Ambientale, Servizio Geologico d' Italia, Roma, Italy, 2011a.

Trincardi, F., Argnani, A., Correggiari, A., Foglini, F., Rovere, M., Angeletti, L., Asioli, A., Campiani, E., Cattaneo, A., Gallerani, A., Piva, A., Remia, A., Ridente, D., and Taviani, M.: Note illustrative della Carta Geologica dei mari italiani alla scala 1:250.000 foglio NL 33-7 Venezia, 151, Istituto Superiore per la Protezione e la Ricerca Ambientale, Servizio Geologico d' Italia, Roma, Italy, 2011b.

Trincardi, F., Campiani, E., Correggiari, A., Foglini, F., Maselli, V. and Remia, A.: Bathymetry of the Adriatic Sea: The legacy of the last eustatic cycle and the impact of modern sediment dispersal, J. Maps, 10, 151-158, https://doi.org/10.1080/17445647.2013.864844, 2014

Trobec, A.: Raziskave zgradbe sedimentnega morskega dna v Strunjanskem zalivu s podpovršinskim sonarjem, MS thesis, University of Ljubljana, Ljubljana, Slovenia, 66 pp., 2015.

Trobec, A. and Busetti, M.: Models of the bathymetry, of the base and of the thickness of Holocene marine sediment in the Gulf of Trieste (Northern Adriatic Sea) [Data set], OGS SNAP System, available at: https://doi.org/10.6092/ 6ad9b1e6-c977-cec9-8a2d-db10c7f90adc (last access: 12 June 2018), 2017.

Trobec, A., Šmuc, A., Poglajen, S., and Vrabec, M.: Burried MIS 5 abrasion platforms in the Bay of Koper (Gulf of Trieste, Northern Adriatic) confirm long-term subsidence of the Northern Adriatic region, EGU General Assembly, Vienna, Austria, 17-22 April 2016, EPSC2016-11963, 2016.

Trobec, A., Šmuc, A., Poglajen, S., and Vrabec, M.: Submerged and buried Pleistocene river channels in the Gulf of Trieste (Northern Adriatic Sea): Geomorphic, stratigraphic and tectonic inferences, Geomorphology, 286, 110-120, https://doi.org/10.1016/j.geomorph.2017.03.012, 2017.

Vrabec, M., Busetti, M., Zgur, F., Facchin, L., Pelos, C., Romeo, R., Sormani, L., Slavec, P., Tomini, I., Visnovic, G., and Žerjal, A.: Refleksijske seizmične raziskave v slovenskem morju SLOMARTEC 2013, in: Raziskave s področja geodezije in geofizike 2013, edited by: Kuhar, M., Čop, R., Gosar, A., Kobold, M., Kralj, P., Malačič, V., Rakovec, J., Skok, G., Stopar, B., and Vreča, P., University of Ljubljana, Faculty of Civil and Geodetic Engineering, Ljubljana, 97-101, 2014.

Yuan, F., Bennell, J. D. and Davis, A. M.: Acoustic and physical characteristics of gassy sediments in the western Irish Sea, 
Cont. Shelf Res., 12, 1121-1134, https://doi.org/10.1016/02784343(92)90073-S, 1992.

Zampa, L. S., Busetti, M., Furlani, S., Baradello, L., and Romeo, R.: Evidence of neo-tectonic tilting in the Gulf of Trieste, in: Proceedings: GeoSUB - Underwater geology, Trieste, 13-14 October 2015, edited by: Furlani, S., Antonioli, F., Anzidei, M., Busetti, M., Ferranti, L., Mastronuzzi, G., and Orrù, P., 72-73, 2015.

Zecchin, M., Gordini, E., and Ramella, R.: Recognition of a drowned delta in the northern Adriatic Sea, Italy: Stratigraphic characteristics and its significance in the frame of the early Holocene sea-level rise, The Holocene, 25, 1027-1038, https://doi.org/10.1177/0959683615575358, 2015.

Zgur, F., Codiglia, R., Busetti, M., Petronio, L., De Vittor, R., Loreto, M. F., Pelos, C., Pettenati, F., and Romeo, R.: Studio dell'evoluzione geologica e tettonica del Golfo di Trieste (Adriatico Settentrionale), Rep. OGS 2010/24 RIMA 6 ADEST dd. 18-03-2010, Istituto Nazionale di Oceanografia e di Geofisica Sperimentale - OGS, Sgonico, Italy, 47 pp., 2010.
Zgur, F., Facchin, L., Busetti, M., Vrabec, M., Slavec, P., Romeo, R., Tomini, I., Sormani, L., Visnovic, P., and Pelos C.: SLOMARTEC: Correlation of tectonic structures occurring onland in the Istria Peninsula and in the Gulf of Trieste (Northern Adriatic), and investigation of their neotectonic activity, Cruise Report OGS Explora, 18-21 March 2013, Rep. 2013/64 - IRI 9 ADEST, Istituto Nazionale di Oceanografia e di Geofisica Sperimentale - OGS, Sgonico, Italy, 47 pp., 2013.

Žerjal, A., Poglajen, S., Rant, I., Soczka Mandac, R., Lovrič, E., and Mencin, E.: Preliminary survey for submarine cable interconnection between Italy and Slovenia, Final Report (Version 1.0), Harpha Sea d.o.o., Koper, Slovenia, 33 pp., 2015. 